\title{
Growth Based on Social Debt, Neoconservatism and the Work of the Researcher in Recent History of Brazil
}

\author{
João dos Reis Silva Júnior \\ Department of Education, Federal University of San Carlos, San Carlos, Brazil \\ Email: jr@ufscar.br
}

How to cite this paper: Silva Jr., J.R. (2019) Growth Based on Social Debt, Neoconservatism and the Work of the Researcher in Recent History of Brazil. Open Access Library Journal, 6: e5726. https://doi.org/10.4236/oalib.1105726

Received: August 23, 2019

Accepted: September 14, 2019

Published: September 17, 2019

Copyright () 2019 by author(s) and Open Access Library Inc.

This work is licensed under the Creative Commons Attribution International License (CC BY 4.0).

http://creativecommons.org/licenses/by/4.0/

\begin{abstract}
The text consists of two parts. In the first, we try to show how the long periods of recent Brazilian history have their origin in the 1964 Coup, carrying in each transition inheritances from the previous period. In the second part, we seek out to show the sociological mediations that are difficult to apprehend in a long historical view. To understand work in general and work at the university, we proceeded to analyze the changes in the Brazilian state apparatus, public policies and civil society. Some conclusions point out to the consolidation of the commodified university, to the hegemony of technoscience, to the establishment of a new episteme that becomes the basis of the commodity knowledge produced through immaterial, overqualified and productive work due to the consolidation of Social-Debt-Led-Growth-Regime and its consequences for the economic periphery of the planet, especially Brazil.
\end{abstract}

\section{Subject Areas \\ Education, Politics}

\section{Keywords}

Commodification of the University, Professor's Work, Social-Debt-Led-Growth-Regime

\section{Introduction}

Charon, son of Erebus and the Night, was an old but immortal god. His function was to carry beyond the Styx and Acheron the shadows of the dead 
in a narrow, ugly, funeral color, boat. He was not only old but miserly; he received in his boat only the shadows of those who had been buried and who paid for his ticket. The required sum could be no less than one obvious and no more than three; That is why relatives put in the mouth of the deceased the money necessary to pay for his ticket [1].

The reappearance of conservatism in society and in particular in education is part of the recent history of Brazil. Brazilian education in particular is permeated by continuities, discontinuities or disruptions resulting from changes in the economy, the structure of the state apparatus, civil society, republican institutions and the constitution of the individual's sociability. Many institutional reforms took place from the 1950s until the first gloss of this century. Having generally originated in the state, these changes sought to change the processes of construction of human sociability, with the purpose of adapting the citizen to the form of the social pact assumed by the country in each historical time (here we highlight the period of construction of the New Republic Pact) and its respective dissolution and consequences for what education has been specifically pursuing, and for our object of investigation, its higher level. What interests us is the understanding of the sharp changes that have been taking place at this educational level and in the organization and legislation of work in general since President Dilma Roussef's impediment in 2016. The text is presented in two parts. In the first part (Part I), we look for elements that have structurally influenced the historical process and education and are still present in the crisis today faced in the sphere of work and work in higher education (this is the moment of the historical view of the context). Already in the second part, we seek to understand the context in which all radical changes still underway such as the program FUTURE-SE and that without the historical aim would lose in understanding. This article is the first of three. Here we seek the fundamentals that led to the existence of the program. The next one to be released shortly after its publication will analyze the text of the law guided by the foundations produced in this article. In the third and last article, history will have brought us the necessary historical density so that we can accurately examine the harmful consequences of the general changes that have been taking place in the country since 2016 and, specifically, the consolidation of New Brazilian University [2]. The two epistemic movements performed in this work are similar, since it is the same view from different moments. The diachronic has the densest perspective in its dimension of history, while the second moment is made in the present tense, hence the necessity of the indispensable help of history. The social sciences are the sciences of the present, if we disregard its past substratum, it will appear here or there, demanding answers from us.

\section{Part I-Brief Historical Overview-The Production of the New Republic Pact}

The 1964 military coup is the result of the contradiction between the economic 
and the political-between a socioeconomic process that sought the internationalization of the Brazilian economy, on the one hand, on the one hand, the national-developmentalist project defended by most congressional politicians of the time that is, from the Social Democratic Party (PSD) and the Brazilian Labor Party (PTB). The military coup of 1964 meant, therefore, a political rupture in the socioeconomic continuity, imposing, by coercive processes, drastic and profound modifications in the social structures, aiming also to reach transformations in the superstructures of the Country, fact that is still deeply embedded in recent history of Brazil. The rationality of the coup guided the New Republic Pact and all the fantastic democratic advances of the 1980s. It keeps organizing the country's entry into the regime of financial predominance and "loses its shame" upon joining (in the face of the crisis of over-accumulation of regime of financial predominance), without return, the Social-Debt-Led-Growth-Regime with the Bolsonaro and his army of Brancaleone which, unlike the picture of the film, can achieve with above average points its objective.

At that juncture, at the educational level, the 1964 military-authoritarian government, under social pressure, sought to increase the "productivity" of public schools through the adoption of corporate administrative principles, and from the outset lead to a gradual privatization of education. This is clearly demonstrated by the Decree-Laws issued by the military government of shift and daytime. In the case of higher education, Decree-Laws No. 53/66 (setting principles and standards for federal universities) and No. 252/67 (which establishes complementary rules to Decree-Law No. 53/66), as well as the various agreements signed between the Ministry of Education and Culture and the United States Agency for International Development (USAID), which oversaw educational reforms and the Brazilian economy in the first military governments. This largely resulted from the central features of the so-called 1968 university reform (Law 5540) and the 1st and 2nd grade education reform in 1971 (Law 5692). The following years were marked by a profound reorganization of the educational field in the country, towards a certain sociability of the Brazilian citizen, as many studies have shown.

However, Brasil Potência Project, expressed in the political program of the military dictatorship for the country, soon showed its limits, when the consequences of the great crisis of social democracy, especially in Europe, and of national developmentalism in Latin America, brought here, associated with the

\footnotetext{
${ }^{1}$ The literal translation for the expression does not say precisely about the rationality of the regime that succeeds financial predominance. It is an overaccumulation regime in which profit does not produce the reproduction of capital, but social debt to the state, on the one hand, and debt from peripheral countries to central economy countries. I emphasize the analytical power of the Marxist Theory of Dependence for understanding the specter of fascism that surrounds Latin America. A viable translation could be the Social Debt Growth Scheme. The Pension Reform in Brazil is emblematic. With the chance that capitalization is most likely approved, society will be indebted for the rest of its life so that it can retire if it lives there, while indebted, to paraphrase Ricardo Reis, institutionally pays the "dark boatman" monthly.
} 
absence of national savings, causing the twilight of the economic miracle ${ }^{2}$ and leading to the imminence of an unprecedented social crisis. With the "re-democratization" of the 1980s, this crisis was politicized under the political, economic and social orientation of the coup during the process of transition from political power from military to civilian hands-from a dictatorial regime to a quasi-democracy and various failed attempts to impose economic orthodoxy as a policy based on monetarism. Just remember the numerous plans made in the country to the Real Plan.

1) February 28, 1986: Cruzado Plan (President: José Sarney, Minister of Finance: Dílson Funaro);

2) November 21, 1986: Cruzado Plan II (President: José Sarney, Minister of Finance: Dilson Funaro);

3) June 2, 1987: Bresser Plan (President: José Sarney, Minister of Finance: Luiz Carlos Bresser-Pereira;

4) January 6, 1988: "Beans with Rice" Policy (President: José Sarney, Minister of Finance: Maílson da Nóbrega);

5) January 5, 1989: Summer Plan (President: José Sarney, Minister of Finance: Maílson da Nóbrega);

6) March 15, 1990: Collor Plan, or "New Brazil Plan" (President: Fernando Collor de Mello, Minister of Finance: Zélia Cardoso de Mello);

7) January 31, 1991: Collor II Plan (President: Fernando Collor de Mello, Minister of Finance: Zélia Cardoso de Mello);

8) May 10, 1991: Plan Marcílio (President: Fernando Collor de Mello, Minister of Finance: Marcílio Marques Moreira) and;

9) July 1, 1994: Real Plan (President: Itamar Franco, Minister of Finance: Rubens Ricupero).

The contradiction between, on the one hand, a profound social and productive deficit accumulated during the so-called "lost decade" and, on the other, the re-democratization of power produced the politicization of the economic crisis woven under the rule of the military dictatorship and not solved in the same historical period. This has weakened social movements and the institutions and political organizations of mediation between the state and civil society. These were the objective historical conditions under which the armed forces, MDB-led politicians as a whole, and businessmen produced the New Republic Pact, largely reproducing the values and political orientations of the Coup. The imminent socioeconomic and political adjustment found the necessary ethus here.

During the 1980s, the Brazilian state apparatus was seen as a major spender,

\footnotetext{
${ }^{2}$ Brazilian economic miracle is a Brazilian historical moment in which there was an economic growth that clashed with the years that followed this period, especially the years of the 1980s. This historical moment of the military dictatorship occurs between 1968 and 1973, when all the indexes of the economy Brazilians were positive. Such growth is due to the positive conditions of the world economy and the positive results of the Castelo Branco Government Action Program (PAEG), carried out during the Military Dictatorship in Brazil, between 1969 and 1973.
} 
intervener, bankrupt, inefficient in providing social services to meet the demand demanded by social rights. The economy was stagnant and inflation at high levels, close to $200 \%$ per month, foreign and domestic debt was large and the default was the exit found by President Sarney, while domestic debt increased at the same acceleration of inflation levels as a result. This situation has imposed on President Sarney the need to issue national treasury bonds, further increasing the already very high public debt. Brazil was insolvent. On the other hand, it is undeniable that since the Amnesty campaign in the late 1970s, civil society seemed to breathe the possibility of the country living a democracy at the end of a bloody dictatorship. In the social sphere, there was a re-democratization of the country as supported by several intellectuals such as [3] [4], among others.

However, the change in relations between the state and civil society was not visible, let alone the agreement made in the late 1970s under the leadership of Dr. Ulysses-the New Republic Pact. However, economists showed the huge deficit in the economy, especially [5]. This picture had a significant bearing on a democracy that began after twenty years of authoritarian military rule and under the guidance of the coup leaders themselves.

The role that social movements and political parties played in this period in demanding policies of social demand is relevant, as can the workers' organization. Noteworthy are: the new unionism led by Lula da Silva, the Unified Workers Central (CUT), with organic articulation with the emerging unionism, the emergence of new parties, especially the Workers Party (PT). Due to this scenario, there was a tendency to strengthen the legislature, for the same reasons as this framework, civil society is organized around the political activity of social demand, seeking to influence the design of the state budget each year.

However, due to the deficit mentioned, the claims could never be met and as a consequence, all political and social movements as well as the legislative power weakened. A weak civil society emerges that cannot organize itself and begins to talk directly with the state. As a result, society has become disorganized, but in an apparent atmosphere of re-democratization. With a disorganized civil society and without the mediation of weakened entities, the legislature has also weakened and the state through executive power starts talking directly to the people, as well analyzed by [6]. This framework of "democratic centralization" produces a favorable political scenario and place for the state apparatus for the adjustment that would take place in the early 1990s, consolidating the New Republic Pact.

This adjustment was seen, due to the ideological reductionism of the state-public sphere carried out by those who defended Brazil's adaptation to financial predominance, as inexorable for overcoming the capitalist crisis managed within the predominant social democracy of the twentieth century and was first present in the Chile and as a Pandora's box then in the United States and in countries in Europe and Latin America. The ideology of the inexorable or the strong argument of "There is no Alternative" that lasted the eight years of Fernando Henrique Cardoso's (FHC) government would be one of the first ar- 
guments and justification for Lula's economic policy option to continue the monetarism of FHC and others who tried unsuccessfully during the 1980s and beyond.

According to the authors [6] [7] at that time in Brazil, there was an official change of speech and debates about the direction of the country. In the past, the debate was about Brazil's dependence on foreign capital, the cepal theses of national developmentalism, of the antagonism between economic orthodoxy and its antithetical heterodoxy, the scant discussion of the Marxist theory of dependence. Faced with an ideology of the inexorable, everything began to revolve around axes such as economic stability, higher added value, new relations with international capital, new relations between national and national capital, pricing or not, stability of financial institutions, low rates. inflationary, financial and commercial deregulation, among many factors that seemed to indicate as the only way out of all the problems of the country, its adaptation to the new moment of world capitalism.

As a result, radical transformations took place in the forms of production of human life in all its dimensions, due to the very rationality of capitalist economic-social formation. The productive base has changed significantly through scientific development and the very nature of scientific doing which, in a dialectical embrace of economic demands, gave rise to revolution 4.0. The economy, in its micro dimension, has restructured in the face of its own movement and of what happened with globalization in the macro sphere. In this context, there is a radical transformation in the relations between large corporations and republican institutions, as well as in their organizational and management paradigm, with the objective of consolidating monetarism, a crucial tool demanded by financial capital.

At the political level, the public sphere is first restricted and deregulated, then re-regulated, thus enabling the expansion of the private sector and new forms of different appearances as the Brazilian public fund is presented, in movement from the State, through structural reforms guided by management theories of the business world, rather than political theories related to citizenship, even if based on the liberal conception. The state even becomes an instrument of production in favor of capital. Institutional changes and reforms seek to consolidate material and immaterial, efficient work in any potential sector for accumulation. It is relevant to highlight at this point that the historical production of what happened to live in Brazil, from 2016, was embryonic ready, but ready, and with the rationality of the New Republic Pact. We reiterate, led by the MDB, then the PMDB, party leader of the process.

\subsection{The Present Moment under Construction}

In this new historical phase, science, technology and information, which used capital in a subsidiary but essential and structural way since the nineteenth century, in earlier phases, become strategic for the strengthening of their central 
productive forces, although in the condition of General Intellect [8] developed under his monopoly. Bond money becomes the main economic asset, due to the expanded mode of capital reproduction through financial predominance, materialized by the world capital market through financial globalization, especially its interest-bearing capital form. Transnational corporations, shielded by financial organizations such as the International Monetary Fund, the Inter-American Development Bank, the World Bank, etc., take the lead, articulated with the governments of central countries, the center of world power, to the detriment of society's longings. Foreign Direct Investment (FDI) becomes the major vehicle of this globalized process. Here the fetish of the need for technological innovation gains a lot of economic strength on the planet and is imposed on the countries of peripheral and dependent capitalism. The ideology of the technological solution is the current discourse. Not only among the intellectuals closest to economics, but also in academic production. The university becomes the center of production of technoscience and Promethean ideology. [9] in dense work on the subject, writes:

Thus, with the slow passing of time, many technologies formed from a few technologies and took on more complex forms, employing as simpler technological components. The overall collection of technologies surpasses itself from little too much and simple to complex. We can say that technology is created from itself. (Brian Arthur, 2009, p. 47).

\subsection{Consequences}

As consequences and structural components of this new phase, unemployment, the decentralization/commercialization of the State (the commodification of liberal democracy and the status of an instrument of production imposed on the State) and the outsourcing of the economy, legitimized by the conceptions, are becoming increasingly widespread. inspired by liberalism, provoking intense process of commercialization of social spaces, and every form of public fund mobilized for capital, especially, in this case, those of education and research in their applied modality (technological innovation/knowledge-commodity/ technoscience products). Although the criticism of the intellectuals was intense, the political, economic and social dimensions had not yet touched the center of the far-reaching process. Such a movement of commodification and the new managerial paradigm of the public fund, due to the new state statute, cause profound changes in the ethos of public educational institutions (themselves a mode of objectification of the public fund, now also instruments of production), through new relations with society and educational reforms based on abstract work, proper to this new historical form of world and Brazilian capitalism, that is, having it as the central axis of its structuring and organization. The relations between capital and labor tend to shape a new field for the educational sphere.

Given the materiality of this situation, workers are induced to assume, through education, a posture of permanent search for continued training to 
make them re-employable. Their subjective qualities must be understood as commodities, something objective to be acquired as a condition for their employability in an increasingly jobless society, a situation resulting from the rupture of the historical rationality of the Brazilian moment that underwent structural change with the "end of the Vargas era", as the then-president-elect Fernando Henrique Cardoso would announce in his 1993 farewell address to the Senate. It is, therefore, the incorporation of the process of blaming the worker in the face of his eventual failure in the labor market. Events that showed strong signs of the end of the New Republic Pact had been produced in society at large, especially among the workers and the Brazilian middle class.

As can be seen, from the second half of the 1990s onwards, various cultural traits that underlie Brazilian social relations are replaced under a new historical feature. The technicist bias of Brazilian education, as an effective means of development, is actualized in a social pact between antagonists and under the auspices of a pragmatic, popular and democratic-looking central government, rather than under the authoritarian dictates of the enduring military dictatorship. An illustration of this is the discontinuity of social movements that demanded public policies to address the social and productive deficit, a legacy of the 1964 period articulated with the result of the 1980s, when non-governmental organizations complained, with or without public resources, national or foreign, what was previously considered the social and subjective right of the citizen. In addition, all social and economic indices worsened until at least the mid-2000s.

Professional qualification and training are a well-rounded example of this break. In the 1990s, for example, in a visible act of conciliation, the Single Workers' Central made intensive use of FAT funds-as did non-governmental organizations such as Unitrabalho. It is now a very complex reality constituted by the condensation of multiple historical realities, so difficult to grasp, but they already show the new status of the state and republican institutions, as well as the new ideological cement of civil society. There was a silent movement that would shake the ideological and partisan sphere in the country.

In the field of public administration, public policies for the social, especially education, once demanded by civil society, became supply policies based on a budget oriented to make the country, by the rationality of the new state statute, subordinated by multilateral agencies and a physiological National Congress. These are state-funded gift policies, a fact that is possible given the reform of the state apparatus and the factors previously outlined. Budget produced under the auspices of the International Monetary Fund (IMF), present and intervening in the country since the early 1980s, when the IMF managed the Brazilian economy through the imposition of economic guidelines through the many and frequent missions in the country. The current historical feature of capitalism in Brazil has produced a process of social control and regulation that seeks the "new institutionality" based on the search for consensus between antagonists, an ideological construction that most resembles an epiphany, through negotiation submitted to 
economic policy assumed since the early 1990s, when the New Republic Pact was consolidated.

By hypothesis, the policy externally negotiated by FHC as a diplomat and initially realized as Minister of Finance with the Real Plan, which became the embryo of his government program politically and economically, and, with changes in strategies and alliances for political practice, was accentuated in the government of President Luiz Inácio da Silva, although the social sphere under the same political paradigm was observed.

\subsection{The End of History and the Culture of Fear}

It is also noteworthy that the economy has experienced apparent and significant advances, which counteracted the real and concrete poverty of the population and the official disregard for the mostly focal and privatizing social policies. Conservative intellectuals act aggressively, taking advantage of this contradiction, and have produced the culture of fear-fear of a hardening of the political regime in the country, reiterated in Latin America, that would be carried out by opportunistic politicians, in a framework of absence of partisan historical density, but in the presence of a political making pregnant with revitalized patrimonialism under new historical forms, which seem to acquire realization of free expression in the words of a Cuban artist with whom I met in January 1990 at the Universidad de Havana "La unidad de Latinoaméricaésunacontradición. De una parte, hay lo retraso imposto por las elites políticas y económicas, de otra, el sueño surreal con la modernidad venida de lugares desde el Norte".

It is therefore a crucial historical moment. It is the scene of a true dictatorship of symbols, the present and the apparent, which obscures the vision and understanding of social reality, when the way reality is presented, given the brutal force of capital over labor, dispenses with ideological mediations and Politics becomes an economic activity. In appearance, everything seems to move so that the whole remains apparently static in the face of human survival effort. The social objectivity historically produced by man is second nature, such as its level of fragmentation, heterogeneity and epiphany. It thus deceives who produces and reproduces it and is produced and reproduced by it. A strangeness never experienced by the Brazilian citizen is produced and seems to permeate the public university institution to silence its criticism. Very expensive position to the university that today is under strong attack of various natures, but, strongly, the ideological one. This same culture, too, would become the social intellect from the "June 2013 Days."

In this historic event it is clear and palpable what has been building as a foundation since the 1964 Coup and has remained in other forms, especially with the cohesive production of the New Republic Pact, which guided the Electoral College instead of the Diretasjá. In the continuity the production of the 1988 Constitution, had been made in the National Congress rather than a National Constituent Council, the gain-at least one-in the debate of the necessity or not of 
a specific law for the education. A struggle followed for the formation of the National Public-School Defense Forum and the discussions that took place about the LDB, only approved in December 1996, when the country was already under the aegis of financial capital. I want to point out that the main victories in the 1980s, but all the major ones originated from the height of the institutional power, were passive micro-revolutions and excellent means to produce the culture of conciliation, having as its foundation the culture of fearlessness. with a lot of blood for the Military Dictatorship.

This illusion constitutes the exact naturalization of what is cruelest, objective and historical: the phenomenal form of contemporary capitalism that is not perceived in the historical and daily production of human beings. Everyday life is marked by heterogeneity, fragmentation and immediacy, that is, the need for human beings to give automatic answers-without reflection on the environment in which they live-their needs. Real scenario produced by space-time compression as a result of the predominance of the financial capital movement cycle, whose movement places today, in real time, an unseen demand, about the capital cycle in function and the cycle of the real production of values. The weight of this movement requires the expansion of spaces for the production of values, spaces formerly state and public, as well as requires greater real production of value (regime that like all others would have its limit). This led to the constant need for technological innovation and, consequently, for the training of researchers and labor market oriented. In this field, public universities stand as strategic institutions for the maintenance of value production and the basis for financial extraction of the total value.

In the context of the foundations of the current Brazilian capitalism, with mediations, can explain the reformulation of the Ministry of Education in the government of Dilma Rousseff. As part of the state reform movement, which becomes a management tool, education itself becomes a commodity. Technoscience and commodity knowledge emerge in state universities.

In the daily universe, the vast majority of society apprehends the world through the superficial and the apparent, taking as its criterion of truth the potency of truth produced by applied knowledge and, as the epicenter of its morality, utility rather than history. Ethics, defined as the science of moral criticism, disappears from society and largely from the intellectuals of the Brazilian left. Human rights derived from citizenship have become commodities for their owners to become as well, while the country, with a state with the status of an instrument of production, reduces the country to an economy with excellent potential for accumulation, becoming the financial platform for the valorization of globalized financial capital, as well as a reliable and profitable financial market in the face of the country's bondage to international capital in all its forms. The New Republic Pact is the nau's guide that would face tidal waves because of the very logic of consensus. It had been produced like a time bomb, would explode soon. A big mistake was to analyze that picture less critically and always guided 
by the historical culture of conciliation.

In this context, observing the field of higher education policies in the last fifteen years and the trajectory of the economy and social policies, which are developed based on the basic principles outlined above, there are many more continuities than ruptures. The new, for the moment, is much more in the plan of the idealized and expressed in two legal instruments, pending in the National Congress, than revealed by effective policies. For example, in the form of a higher education reform law, it seeks to establish general and regular higher education standards in the federal education system, amending Law No. 5.540/68 and a set of other supplementary laws concerning education, particularly higher education, with an emphasis on applied research and mass certification of the working class.

Of course, no PEC or law encompasses all "reform" or all public "policy" underway in the field of education or any other specific area of public social policy. Fundeb's reach and limits derive from the educational policies and practices of recent years, which can be counted in decades, although the most recent ones predominate. It is the contradictions of the economy and sociability constituted under the domination of capital, with its contemporary face, that condition the essentials of the educational policies and practices constituting the ongoing "reform", which would accentuate and acquire traces of a conservatism that possibly would make Edmund Burke ${ }^{3}$, an eighteenth-century conservative English philosopher and politician, a severe critic.

Among the most important aspects of educational practices in Brazil, one still stands out, which has been an essential mark of the reform of the state apparatus, sponsored by the government of Fernando Henrique Cardoso (FHC) since 1995, that is, the managerial dimension that should preside over this reform of the state apparatus extends to the administration and management of basic education and public schools through the new configuration and management of the public fund, given the status assumed since then by the state. In addition to the administration of the state apparatus and public policies in a financial-market manner, the thesis that education, especially higher education, is a private service good is spreading and strengthened. The Brazilian education instead of composing the public sphere, because the educational institutions become executing organs that must be guided by the rationality of the market.

At this level would be the solutions to all the ills that have afflicted the country for over 500 years: the panacea for the production of science, technology and technological innovation. The university is dismantled as a privileged place of doubt, debate and criticism to put in place the professional university, an agency that executes public policies under state competence. Here we highlight the ob-

\footnotetext{
${ }^{3} \mathrm{~A}$ famous 18th-century English politician, Burke was well known when he wrote his Reflections on the Revolution in France, published in November 1790. Chosen in 1765 as the private secretary of one of the Whig party leaders in the British Parliament, in 1770 he wrote a pamphlet-Thoughts on the Cause of the Present Discontents-in which he argued that King George III's increasingly active intervention in government affairs was lawful against the spirit of the British constitution. Retrieved from http://www.arqnet.com/portal/teoria/burke.html.
} 
jectification of the new statute of the state apparatus. It would be up to this agency to predominantly constitute, on the one hand, the producer of knowledge potentially applied to the actual cycle of capital production, technoscience, on the other, the lifelong training of a skilled workforce for a flexible market for work under the heavy heel of finance capital. But the structural crisis of capitalism would take all of this to a darker and deeper level.

The central dimension of the reform of the state apparatus, as well as the platform for the production of a new legal order, was to redefine the legal concept of private property. In capitalism, the movement of transformation of communal, public, communal properties, etc. on individual private properties is unique to its historical nature. After [10], many public rights were turned into private property, and foreign financial capital found in this definition a huge space to gain wealth for its rotten roles entering the country. This is a central point in understanding unrestricted outsourcing, the end of CLT, and the cheap delivery of our national properties to the United States. It is also the basis for a structural demand posed by finance capital. The financial predominance regime is exhausted. It is impossible to produce concrete profit to support the bankrupt mass of bonds, dividends and promises of future profits that turn around the world. Here, as in 1929, one arrives at the over-accumulation of capital. That is, excess capital and the impossibility of producing new real values, as analyzed by [11].

It is the logic of capital, founded also on the idea that private goods produced and reproduced themselves on the impulse of competition or competitiveness, to gradually and rapidly impose themselves in the fields of education and knowledge, now much more valued than once as an important commodity of the new modes of accumulation, thus forms the basis of technoscience. The science produced has at its center economic rationality. Consequently, the knowledge produced is the commodity knowledge, the researcher's work is immaterial, overqualified and productive. The worker, in this case the researcher, does not place his knowledge and existence in favor of the demand of the human condition, but by increasing new values in the face of the explosion of the supply of fictitious capital on the planet. Before long, the researcher strangers to the object of his work, the method and the times of the work, also kept under a chaotic and compressed space-time relationship that is imposed on him. As a result, the scholar is strange (unrecognized) to the object, his work, the institution, and himself. Suffers, gets sick and often dies.

\subsection{Public Fund and University}

The bill on higher education reform, which, breaking with the continuity of previous policies, would aim at strengthening the public sector (with effective autonomy, would guarantee funding to meet current and expanding needs, increase the percentage of enrollments in up to $40 \%$, etc.) and regulation and control of the private sector (by curbing the expansion especially of commercial 
private companies, significantly increasing qualification requirements, and fully linking students, etc.) is constrained by many factors as follows: You can see this brief review. Still, with infinite amendments has rested in peace in the National Congress for over a decade and a half. First of all, by the development model and the characteristics of the macroeconomics, which continue the neoliberal adjustments promoted since the Collor de Mello administration, consolidated in the two FHC mandates and continued by President Lula's two, Dilma Rousseff's 1.5 and 0.5 of Temer and a few months of Bolsonaro through different political alliances and practices without, however, altering the rationality originally produced in the early 1990s, albeit with failed attempts since the early 1980s.

This model makes social policies state commitments of the second order. In this sense, the budgetary resources allocated to them could not jeopardize the basic guidelines that guarantee the country's governability, in the context of the financial globalization of capital and the growing national subservience to international capitalism. We have become a platform for value production and an excellent market for sustaining homeless financial capital, but the basis for the well-being of central economy societies and their dominion over peripheral economy societies.

The number one priority is the payment of external debt service, guaranteed by exorbitant indices established for the primary surplus, the tax cut, among other measures. Or, more broadly, since the period of the FHC government, followed by the Lula, Dilma, Temer, and Bolsonaro governments, all institutions and companies, notably the public university, have been placed at the service of capital appreciation to transform Brazil is one of the main platforms for the production of value and an excellent market for financial capital to sustain the overproduction of financial capital at the planetary level, in a complex process of updating the Marxist Theory of Dependence. How to believe, therefore, that it is approved, first in the National Congress, then sanctioned by the Presidency of the Republic, after hearing the financial area, a financing proposal, for example, that covers current needs, recovers the deficit of the previous ten years and guarantees the expansion of the public sector of higher education to reach $40 \%$ of enrollments, with guarantees of maintaining the identity of the university institution?

The proposed higher education reform law is conditioned by previous legislation that regulated, by decrees and ordinances, in past governments, essential aspects of the National Education Guidelines and Bases Law (Law No. 9394/96). Only Lula considerably expanded higher education through programs such as ProUni, REUNI, FIES, Rousseff tried, when he suffered the coup, to accelerate Brazilian research for the production of Technoscience. However, it is necessary to emphasize that the biggest and most immediate constraints derive from legislation approved during the two Lula administration mandates, with organic articulation with the Dilma government directives that had announced the third phase of the expansion of federal higher education and consequent structural 
change. its institutional culture along the same lines as the governments of the past twenty years. The centrality is the public financing of the production of technoscience.

Among the legal instruments passed under federal administration in the 2000s are three other laws that directly or indirectly affect the higher education subsystem and condition the university reform law. Not to mention the approval of the National Higher Education Assessment System, replacing the National Examination of Courses (Provão), which was then under test and under important criticism as to its effective respect to university autonomy and even to its efficiency, as well as to its effectiveness. The new forms of access desperately sought by the then Minister of State Fernando Haddad, who seemed to have flaws of varying natures.

The first of these laws is No. 10973 (Technological Innovation Law) of December 2, 2004, which provides for incentives for innovation and scientific and technological research in the productive environment. It creates incentives and facilities for companies to utilize the resources-physical, material and human-of public universities. It allows the transfer of technology developed in universities to private organizations, enables the allocation of public resources in innovation projects and provides for the reward of researchers whose knowledge will be harnessed by companies. Considering the extremely low salary of professors/researchers of public higher education institutions, it is expected that there is an important exogenous interference in the university agenda, contributing to accentuate the increasingly evident features of heteronomy in university life, rather than constitutional autonomy, never actually realized. All that had been much criticized would get worse.

The second is Law No. 11079, of December 30, 2004, which establishes general rules for the bidding and contracting of public-private partnerships (PPPs) within the scope of public administration. It establishes and enables the partnership of the State with private companies in the most different areas of production and trade of goods and services of public and collective nature, that is, research, technological development, environment, historical and cultural heritage, including education and teaching. The assumption to justify the establishment of PPPs would be, on the one hand, the low state investment capacity and, on the other, the supposed private managerial superiority. It is evident that the implementation of PPPs will strengthen the new state statute, as Public Fund resources will be managed-as a natural source of profit and appropriation-by private and non-profit entities and organizations, especially for valuation of financial capital.

Finally, Law No. 11096 of January 13, 2005, which establishes the University for All Program (ProUni) and regulates the work of charitable entities in higher education. With this law, under the pretext of "publicizing" the private and in a broad application of the spirit of PPPs in higher education, private commercial educational institutions are strengthened, in exactly the opposite direction as one of their core objectives, the new higher education reform law forwarded by 
the executive branch to the National Congress for discussion. Instead of creating hundreds of thousands of vacancies in public universities, for what would already be physical space at night (close to $70 \%$ of enrollments were daytime, a percentage that with the Plan of Support for the Restructuring and Expansion of Federal Universities (REUNI) has declined in recent times, but with low effectiveness and serious consequences for the professor's work), at low cost and reasonable quality, the possibility of exchanging about $10 \%$ of the vacancies of private institutions or $8.5 \%$ of gross revenue, in the form of scholarships for students from public schools, among others, in exchange for exemption from a set of taxes. These three laws and Rousseff's central aim in changing the episteme of Brazilian science formed the basis for the President's promulgation of the Brazilian Bayh-Dole Act: The New Legal Framework for Science, Technology, and Innovation.

Given the strength of national and international private education lobbying over the National Congress, which has been manifested with rare efficiency in reconfiguring Dilma Rousseff's governmental proposal for ProUni, it is to be expected that not only current legislation will become a complete hindrance. Effectiveness of the law, if approved as it was sent to Congress, but, above all, will be the changes that there, in the supposed house of the people, may suffer the original proposal. Once again, the State objectifies in these laws its status as an instrument of production, with structural consequences for the work of the public university professor [11].

Resuming, to close these reflections, the motto of the culture of fear, which results from the reactionary exploitation of the contradictions generated in the confrontation of apparent economic advances with the concrete upsurge of poverty, misery and exclusion, it can be said that this culture-in the national socioeconomic scenario-it finds a place institutionally organized by educational reforms for their most efficient diffusion. It discovers in the reforms a space that enables it to become, on the one hand, the best strategy for the neoconservative offensive and, on the other, the embryo of the educational perspective for the 21 st century, which, more precisely, should lead to the formation of human beings tend to be lonely, dumb, frightened, helpful... and inhumanly unfreedom, being the professor in general, but emphatically that of the federal university institutions of higher education (IFES) a victim who does not think so. In this context, the public university institution with the same state statute will produce a university culture similar to that of society and the change in the nature of the

${ }^{4}$ The Bayh-Dole Act or Patent and Trademark Amendment Act (Pub. L. 96-517, December 12, 1980) is United States law that deals with intellectual property resulting from federally funded research. Sponsored by two senators, Birch Bayh of Indiana, and Bob Dole of Kansas, the Act was adopted in 1980 and is coded in 94 Stat. 3015 and 35 USC $\$ 200-212$ and is implemented by 37 CFR 401 . The main change made by Bayh-Dole was in the possession of inventions made with federal funding. Prior to the Bayh-Dole Act, federal research contracts and grants required inventors (wherever they worked) to assign inventions made through federal funding to the federal government. Bayh-Dole allows a university, small business, or nonprofit to choose ownership of an invention in preference to the government. 
professor's work giving new meanings to the work of this professional.

Given this perspective, there seems to be nothing more than indignation and resistance, which, in everyday life, could translate, due to the relative autonomy still possible in school and university institutions, in the implementation of reforms inside out, making universities agencies executors of public policies under State competence. In other words: seeking to overcome human misery, subservience and exploitation, hallmarks of past and present history, and to realize effective practices of human intensification whose greatest value is freedom. The federal university becomes the executing agency of public policies of state competence in two dimensions.

On the one hand, especially in the field of postgraduate study, the university trains high-level researchers to largely meet the ongoing need for changes in real value-producing conditions and in the management of living labor work. The reorganization of the university under the guidance of technoscience has found good cover among most university professors and advocates of an institutional model: The Entrepreneurial University. On the other, especially through the Federal Institutes of Technology, the courses that joined the REUNI and finally, the Open University of Brazil developed through the distance education modality, performs the mass certification of the working class for a job market, which is reduced and whose constant is its flexibility and change in the general conditions of real production of value and management of the worker.

In this dimension the university fulfills the strategic role of the lifelong learning of a worker with rapidly changing technical knowledge and the new sociability present in the country. Therefore, in addition to structural change in the federal institution of higher education-it also becomes an instrument of production-teaching work is intensified and its relations are precarious [12] which contributes to a degradation of human relations among the workers of these institutions, having as a minimum result the intense and prolonged exposure to the strangeness of their work, the result of it and of themselves, therefore, prolonged exposure to the condition of much suffering. What happened to be denied in the eyes of the astonished viewer?

\section{Part II-Reconsidering Brazil's Recent Reading under the New Context of Capitalism's Structural Crisis}

What was presented in the previous item consisted of an overview of the recent history of the country and of higher education. A photograph to show important facts of Brazil coming to the year 2019, having in front of the Republic a stateless and servile president to the US imperialism. In 2014, when visiting professor at Arizona State University, Daniel Schugurenski and I wrote an article about the administration of Obama in the North and Rousseff in the South, and we were already pointing to an exacerbated neo-Americanism loose in the air of the late 2010. But we never imagined it. Trump in the USA and Bolsonaro in Brazil just one of our misconceptions. This was beyond any spectrum of analysis by politi- 
cal and economic scientists in the world. Ahead we will seek to show the strength of the New Republic Pact and the chaos that its disappearance left, leading to an aimless social stage to demonstrate that only extremes appear as a solution. Especially when the regime of financial predominance shows its limits and everything that was built according to its guidelines begins to fall, and the transition that presents itself is frightening: the old is not dead and the new is not ripe to be born. We point here to the knot that impedes the understanding of a world civilizing crisis. Financial dominance shows its downfall and the social-debt-led-growth-regime shows its strong and destructive rays. Far beyond the downward trend in capitalism's own rate of profit, over-accumulation shows the structural financial instability of the world system, a process that has been going on for almost half a century but has shown its acute momentum in the 2007-2008 crisis. In this period, it was explicit "the fact that expectations of appreciation through excess value have diminished" [11].

For [13] [14] there were three moments in the recent history of capitalism that postponed the larger crisis that inaugurated the social-debt-led-growth-regime. The first was the advancement of neoliberal packages linked to the Washington consensus revenue. The second was the discovery of China as anmense space of accumulation, a fact that made it possible for the country to join the Trade Organization in 2001. The last of these moments, observed by Chesnais, analyzing China, lies in a "sort of capitalist growth" driven by the accumulation of rights over the surplus value to be produced in the future [11]. That is, over-accumulation again requires the exogenous expedient of capitalism in order for it to maintain its historical rationality, the worldwide establishment of the regime of dispossession. It also concludes with the luxurious help of the writings of the intellectual women Luxemburg and Arendt that capitalism from time to time needs to resort to exogenous strategy to rationality itself to continue to change and, as in the case of primitive accumulation and the 1929 crisis.

\subsection{The 1980s}

The 1980s are a central period for understanding what we live today. There is intense debate among political scientists, economists, sociologists and other intellectuals from various fields of knowledge. My position is to seek articulation of what everyone produces, anchored in the evidence available in profusion, after more than 30 years. I hold the position we expounded earlier. The political wear and tear of the dictatorship and the high economic cost of maintaining it in the imminent context of economic depression made the military willing to argue. On the other hand, domestic and foreign entrepreneurs feared bankruptcy, but in addition, they saw in Brazil, as [14] observed in China, an excellent possibility, if molded in its own way, a very large source of profits. Politicians from all parties also sought to break out of the dictatorship imposed and to seek the alleviation of massacres, lost rights and the establishment of a full democracy and 
rule of law, at least in terms of discourse.

These are the objective conditions for the constitution of the New Republic Pact. In the General Amnesty movement, it could already be seen that the great deal had been made by the conciliation and solution intellectuals above (Passive Revolution for Gramsci). And so, it was done despite the emergence of the PT and the discreet protagonism of the Trotskyists who were at the origin of the workers' party.

As we explained earlier, the facts that led to the re-democratization of the decade were the result of an exit commanded mostly by the bourgeoisie who have always been in power. In addition, that agreement carried a great deal of the rationality of the 1964 Military Coup.

We can say that the state would be redesigned according to internal forces thus in equilibrium, on the one hand, on the other, considering the relations with the central economy countries. These latter relations were shaped according to the history that Brazil had with each country, but always as a country of dependent and peripheral capitalism and, therefore, with historical, asymmetrical and structural relations between center and periphery. Regardless of the left's analysis, civil society was organized by the hegemony of conciliation and dependence. Few and laudable movements sought the solution that could historically lead the country to its deserved sovereign status. In addition, it is noteworthy that they were little heard, as well as made little difference in the results on decisions that would influence the direction of the country. Following the elections through the electoral college, society returns to the streets claiming the installation of a National Constituent Assembly.

The proposal demanded by the street movements consisted of the election of a Constituent Congress, once the constitution was finalized, such a congress would be dissolved and the parliament elected for the proper mandates would continue. It would be an excellent strategy for diverting (bypassing) the process of coordinators of the pact that had been made so that power could be passed to civilians. Again, such a dynamic was not possible and the new Constitution was conceived by the Congress formed under the guidance of the New Republic Pact. The 1988 Constitution, from what we have been arguing from the beginning of the text, is but a small institutional spasm compared to the institutionality imposed by the 1964 Coup.

In the same decade, some points were successful in the educational field, such as the demand for a specific law for education (the LDB) and the foundation of the National Forum in Defense of the Public School.

Regarding LDB, conciliation once again prevailed. In 1988, the Brazilian Conference of Education, held in Brasilia, produced an LDB proposal in the form of a bill. Based on a proposed LDB project by Demerval Saviani, Jacques Velloso and Jorge Hage, Deputy Otávio Elísio (PSDB-MG) presented the project to the House, thus taking precedence over any other project that came from the Collor government. The project started, and soon Collor asked Darcy Ribeiro to pre- 
pare a project for Brazilian education. Again, the conciliation would take place with a master stroke and high by the government. In the end, LDB was very different from the two projects, but certainly much further from the collectively and democratically conceived project at the 1988 Brazilian Conference of Education, if there was no Darcy project. The point here is that the 1980s was a period of re-democratization, however based on Brazilian conciliatory culture, accentuating the New Republic Pact.

\subsection{Direct Election and the New Republic Pact}

After an improper election by the electoral college, but on the heels of conciliation hegemony, we had the opportunity for universal suffrage disputed by a former metallurgical worker and a representative of the Northeast colonels.

Collor was a senator for the Christian Labor Party (PTC), until very recently he was not taken seriously when calling himself a candidate for the succession of unpopular President Sarney. Stronger names with historical parties appeared first, such as Ulisses Guimarães and Mário Covas. There was a fear of the establishment of leftist candidates like Leonel Brizola and Lula da Silva.

The campaigns were intense and in a tone of war revealed. The debates were fierce, with the advisers assisting in the debate and discussing the rules of the event. The whole media supported the president of the tiny National Renewal Party. Collor presented himself as a Christian, progressive with much social concern, and defined himself as a Christian Reformist. An interesting detail occurred when Collor paraded in Rio de Janeiro with the "V" of victory, gained the sympathy and support of then Councilman Jair Bolsonaro.

Very popular Lula, was supported by the Popular Brazil Front composed by the parties Communist Party of Brazil (PC do B), Brazilian Socialist Party (PSB), and based his campaign on its union base. It was consistent with his career and prominent intellectuals such as Florestan Fernandes, Francisco de Oliveira, Paulo Arantes, among many others, supported the candidate.

The elections were for the second round and Collor, considered by critics to be populist, Christian, Mussolini's imitator, was raised to the status of "savior of the fatherland" in a context that was very bad with hyperinflation, badly seen outside the international community, with a moratorium in the 1980s, which ultimately favored the candidate thus enthusiastically presented by the media.

The campaign speeches kept the tone, but accentuated the differences widely spread by Rede Globo in favor of the candidate Collor de Mello. Lula remained true to his origin and did not make a conciliatory campaign especially with regard to the business community. Abílio Diniz went to the press and stated that if Lula won the elections he would move country.

With a lot of media help and prejudice against the poor, Collor wins the elections, driven by right-wing populism. It was the alternative of the national and foreign bourgeoisie to produce a globalized country project following the 1964 military coup-winning project. In an attempt to do his job, Collor sought to re- 
make the economic structure with meager and bizarre measures. However, it left a starting point. Criticizing the cars produced in the country, claiming that they were "true wagons", without proper preparation, opened the Brazilian economy to the world economy. In this historical moment began Brazil's Adherence to financial predominance. Maintaining the eternal discourse against corruption, proclaimed himself "The Hunter of Marajás". He sought to save for the country, given the economic bankruptcy left by Sarney, freezing the savings of Brazilian citizens and causing much confusion early in his government. It has limited funding and bank account withdrawals and is corrupted by coordinating its PC Farias bribery operation, which, after all, would eventually be murdered as a file burner without the country being able to set in motion the project intended by the industrial and financial bourgeoisie.

It was not difficult to get him out of office in the face of bad management, attacking the institution "National Savings Account", a role of "superman" that sounded ridiculous. The $\mathrm{ABI}$ and the $\mathrm{OAB}$ requested impeachment from the president and the same media that elected him produced a mass campaign to overthrow him. Students and other segments were urged to take to the streets and promptly attended, the media explored the youth who painted their faces with two green and yellow stripes-the "painted faces" - in a climate of resounding nationalism. Collor was prevented and took over Itamar Franco who would do exactly what was then needed to change the country's project. He was a statesman for the purposes of the bourgeoisie referred to.

\subsection{Brazil towards the New Historical Project}

Itamar Franco was sworn in as President of the Federative Republic of Brazil and served in various areas, but his central objective was to make victorious, in universal suffrage, Senator Fernando Henrique Cardoso, elected by the bourgeoisie to do what Collor could not. It managed the economy without shocks and freezes. It sought to draw up a good foreign affairs policy through its Minister Fernando Henrique Cardoso. And another herculean triumph was to bring FHC to Minister of Finance. As such, he sealed a national alliance between South-Southeast intellectuals and the Midwest, Northeast and North colonels. Everything was ready for adherence to financial dominance.

Cardoso had created a group of leading economists such as Pedro Malan, EdmarBacha, Persian Arida, Gustavo Franco, Gustavo Loyola and Bresser-Pereira. All or most of them had attended the Washington Meeting that produced the Washington Consensus. It is worth highlighting here two points. The first refers to the very reason for the existence of the meeting to which more than one hundred countries from all over the world took place. The major concern was the imminence of a structural crisis of capitalism that was already present, as we pointed out earlier, in the first stage to postpone the structural crisis of capitalism, indicating that its sharpening would require exogenous measures to the mode of production itself, to democracy and the rule of law. The second aspect 
to highlight was the Brazilian delegation present at the meeting. Real Plan parents, Central Bank presidents, etc. attended, and it can be said that the genesis of the future Plan occurs at this meeting. In fact, the guidelines approved in the Consensus have guided over 60 plans worldwide. In addition to being electoral, the Real Plan changed the fundamentals of the Brazilian economy to Brazil's adherence to financial predominance. This would have been Collor's role, but FHC was the one who succeeded.

The Real Plan was widely accepted and gave FHC such popularity that it won the 1993 elections against Lula da Silva in the first round. Cardoso embodied conciliation and servility, and Lula was still persistent in maintaining the Workers' Party, a class party. It had not folded in two elections. The Real Plan changed the country and, through financing with government bonds, thus with the increase of public debt, kept the public accounts in balance and the inflow of foreign capital (in the form of Foreign Direct Investment-FDI) moved the Brazilian economy. In addition to consolidating the Pact, it now planted the seeds of Brazil's "New Dependence" on central economy countries. Education, science and technology were already directed towards what is explicit today and which were briefly outlined in part 1 of this text.

At this time, the main economic variable is the debt that was already large with Sarney, is increasing with FHC. FHC's first term, despite bumps due to the banking crisis of the late 1990s, was well evaluated in the popular arena and with the domestic articulation made when Itamar's minister, he would win the second election against Lula da Silva, still defender of a working class.

\subsection{Financial Predominance and the Structural Need for State Reform}

The entry of foreign direct investment (FDI) substantially altered the Brazilian economy, requiring the expansion of individualized private property, but in different forms from those that existed and fetishized something new required in the fantastic era of globalization. Marx in his work wrote that the process of enlargement of this regime is a constant in capitalism. Since, without the individualized private property regime, there is no exchange value and no money in the framework of the reproduction of capital. The globalization of capital takes place through the predominance of interest-bearing capital over working capital and value-producing capital.

The vertigo of making money based on one's own money without the mediation of labor has brought a squeeze on social work and living work. That is, the financialization of the economy in the world imposed the need and the construction of new spaces for the realization of paper capital, bonds that are nothing but promises of payment and a bet that money capital would value in the future. Capitalism has become a global roulette. This fact brought structural vulnerability to the globalized economic system. Therefore, the urgent need for real-time control of many work processes, the world monetary system and the 
extension of services in the sphere of capital circulation that is expanding and demands organizational systems, information technologies, inaugurating a large space for new technology industry that already existed in profusion thanks to the 4.0 revolution.

However, this process precedes the state guarantees and institutions for the entry of financial capital and FDI in Brazil and the economic stability so that the return is guaranteed with repatriation of profits, leaving in the country the smallest part that is still charged for debt repayment. It is noteworthy, however, that the greatest need for the country due to adherence to financial predominance is the structural production of new spaces for individualized private property. Fact of structural reason and that requires the change of the shape of the apparatus of the Brazilian state, on two fronts.

The first is the institutional construction of rights to new forms of ownership and value. At this point, Bresser-Pereira revealed his acute intellectual capacity in his intellectual production in the service of the creation of such institutionality.

In his book Economic Crisis and State Reform in Brazil: For a New Interpretation of Latin America, given to the public after the policy Plan for the Reform of the State Apparatus, Bresser-Pereira produced the necessary alliance with the Brazilian academy, and at the same time, it achieved political legitimacy for the reforms of Brazilian republican institutions. The whole design of the reform of the state apparatus and republican institutions is very well done and with rigorous theoretical production, although it can be criticized as can be seen. But in the reform, the author shows the institutionality and construction of the new forms of individualized private property, a requirement of the country's adherence to the regime of financial predominance.

The second is imbricated in the first and operationalizes the creation of the alluded space. The construction of the institutionality of the new forms of individualized private property became, at the same time, their operationalization. Bresser-Pereira, by creating two exclusive state nuclei and two non-exclusive or competitive sectors of the state, produced a reduction in state participation in the public sphere, leaving financial capital a huge space for the expansion of individualized private property and property of value to be realized in the future. Herein lies the structural imposition of major changes: unrestricted outsourcing, labor reform, and social security reform [2].

This process is also the transformation of social rights into individualized property rights. With the reform of the apparatus, it changed the rationality of public management in the country, making it a managerialist along the lines of the management of a private corporation. In fact, the state became an office for the management of Brazil as a platform for value production as we have been arguing in other works [2]. Such rationality has arisen for all republican institutions, specifically for the state university. What has been synthetically presented here about work at the university is found in the other works of the author see in 
$[2]-[12]^{5}$ and researchers ${ }^{6}$.

\subsection{Lula Bends to Conciliation}

It is heard from unreliable sources and in the street bullshit that Lula would have said that if Jesus were to rule Brazil, he would have to make an alliance with Judas. The fact is that after three defeats in the country's majority elections, Lula accepts conciliation and wins the 2002 presidential election.

Lula begins his government, disappointing the vast majority that had elected him president of the Republic of Brazil, for not breaking with the submission to financial capital. In taking over the presidency, he said a clear yes to the order established and well translated by Fernando Henrique Cardoso, according to the culture and history of the country. Pressured by his commitment to Bush, as shown by [15], Lula eventually produces, with much pragmatism and charisma, Lulism. This particular form of upside-down hegemony-indeed, a class-reconciling strategy of Workers' Party governments-keeps the country as a platform of real value production [16] for the materiality of incoming financial capital, especially from the United States. On the other hand, it sought to treat the social through compensatory policies and income distribution, bringing a large portion of society to the political scene through access to private and public goods never reached by this class fraction in more than 500 years of Brazilian history.

However, given structural social, economic and regional differences, access to income has never been realized. There were two consequences: 1 ) Lula became the myth and grew larger than the party itself; and 2) needed to consolidate this hegemony and increase the economic productivity of the country by increasing industrial productivity and, at the same time, seek support to continue the production of the new possible legal system due to the reform of the state apparatus, allowing loopholes in the public sphere for the production of raw material knowledge.

At the end of his second term, Lula left Planalto Palace with greater popularity than when he had entered his first term in 2003. The economy has grown, the minimum wage has risen above inflation, there has been an increase in payroll-deductible loans to the underprivileged classes, many social programs have been created, the main one being the Bolsa Familia Program. It is noteworthy that the condition of the world economy was very favorable and neutralized the negative effects of the contradictory adherence to financial predominance and the pursuit of an increase in productivity based on productive investments.

\subsection{Lulism in Dilma Rousseff's Term}

With the popularity with which he left the government it was not difficult to support the election of Dilma Rousseff. Rousseff's first term was stable and the world economy was still growing, although it did not maintain such a positive

${ }^{5}$ Retrieved from https://orcid.org/0000-0003-2667-0371.

${ }^{6}$ Retrieved from http://www.redeuniversitas.com.br/. 
curve for a long period.

Dilma sought to increase the Brazilian economy through the plans of acceleration of the economy, the PACs, among them the PAC of technology that induced in Brazil to its similar; a law that in the United States fostered a strong research and industrialization program at the same time, which opened the space for the hegemony of technoscience the Bayh-Dole Act. In the country's history, the record for investment in research to accelerate technoscience and induce the increase of economic growth occurred between 2014 and 2015, during the Dilma Rousseff administration. Even if one could criticize that it was technoscience, commodity knowledge, the work of a productive researcher, and the state university as part of the value-producing world chains, it was an act of non-servitude.

And just as in the North, here science has also changed, transformed the kind of knowledge and, fundamentally, the work in universities. While ruling under world economic growth, Dilma threatened to lower interest rates, then the world economy suffered the first earthquake after the 2008 capital crisis. The Brazilian economy goes down and a rapid process of deindustrialization sweeps the country. Dilma's popularity falls to the lowest levels and national savings stop, politically the country is not well, there is no foreign investment and the crisis known as the June Days in 2013 emerges. This crisis was not aimed at what its actors claimed. It was a hegemony crisis that was surely shaped by the demand for public transport.

However, those who analyzed it, understood nothing and acted politically wrong. Much more was at stake: The New Republic Pact was fading. The movement in the streets showed very different social sectors: the middle-class citizen, students, students from the periphery, students contemplated by the social policies of Lulism and violent groups such as the Black Blocs. Here was a hegemonic crisis against every political establishment in the country. I speculate that the populist left of Lulism saw nothing but claims. However, it was much more and the 2014 elections were knocking on the door.

Figure 1 shows it is important to note the concentration of income in the world and in Brazil. This fact denies the vast majority, in a context of financial predominance, access to income. According to [17], on the average of the world pyramid, a rich man can earn up to $\$ 1.5$ billion a day in the financial market. You will never spend such an amount. Therefore, it will apply again. In Brazil the same occurred. The invisibles that Lula put on the political scene through the consumption of material and cultural goods never had access to income. There are two consequences if we articulate the political dimension, the party politics, the actors of the June Days and the economic, specifically the financial predominance.

At first, the value of democracy and the rule of rights loses strength. It is disregarded for not producing social stability in the world and in Brazil. In Brazil, with great media support and highlighting Rede Globo, a real war is being waged against the Workers Party. Reconciliation charged your account. But what was 

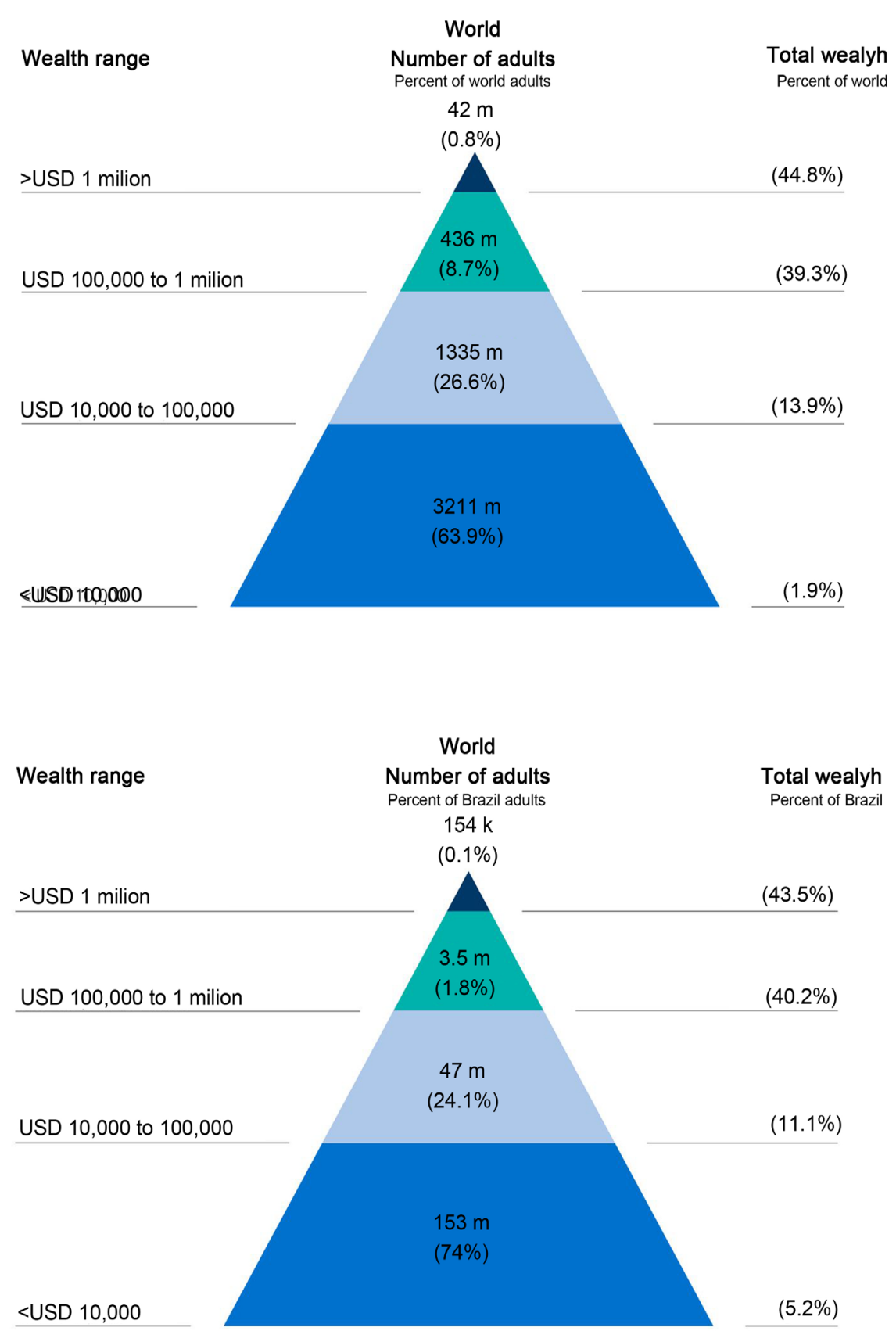

Figure 1. Pyramid of global wealth (2018) and pyramid of wealth in Brazil (2018) Source: Author's own elaboration based on Global Wealth Databook 2016-2018 indicators, Credit Suisse.

hidden certainly presented the greatest danger. The financial predominance entered an overaccumulation crisis as previously analyzed and the reflections on Brazil would soon become concrete. That is, the offer of capital no longer produced the new value needed, specifically by the example given of an investor who cannot spend $\$ 1.5$ billion a day and reapply the amount or part of it.

The world economy is already changed and the political and social consequences followed shortly thereafter. The fear of losing control of the capitalist 
system brings the most conservative policy forward, just look at Latin America, the United States and many European countries.

In Brazil, immediately, the consequences were present. There was a need for real gains on social human work. The 2016 Coup is the pure expression of this change and Brazil's "New Dependence". Fear takes over with this mission. Again, the PMDB is the president's main actor in seeking the stability of capitalism guided by the new accumulation regime; unrestricted outsourcing and labor reform. The social cost of labor decreases radically, enabling an increase in value ownership rights to be realized in the future. However, Temer's wear and tear and his joints put him in the worst condition a president could have been in until that moment in history. Upon leaving office and losing his privileged forum, he was soon convicted and imprisoned.

The 2018 elections were cleaved by the disappearance of the New Republic Pact. All candidates linked to the political establishment during the pact achieved nothing. The dispute was for the second round between Jair Bolsonaro and Fernando Haddad. Haddad was the symbol of hatred for the PT and the political establishment that had been executed on the June Day. Bolsonaro takes over without a publicly exposed program, but with alliances with the military, evangelicals, with parallel powers and with which is more conservative in any social setting. Faced with this, education became its incessant target and the university its great fear and main target of attacks, especially the ideological one. Does everything indicate in these 100 days of Bolsonaro's rule that the worst is yet to come? Why?

\section{Conclusions}

The touchstone for trying to make a contribution to understanding the current ultraliberal and ultra-conservative context seems to be in observing the concentration of income in the world and in the country, resulting in a critical juncture of over-accumulation and the exogenous strategies of capitalism to follow as is. Such a condition is the central basis of prevailing authoritarianism and a conservative return proper to England in the times of Queen Victoria. In a context like this, the university is historically the first institution to be hit. Therefore, if we make ethically critical of the transformations of Collor State University to the present, now, unabated, the critique must be more radical as a struggle and as an epistemology, that is, the critique that goes to the root of the setback that puts the country in mire.

The first point to be highlighted is the Brazilian process of consensus and conciliation production that only led the country to a bad place. It must be considered in the populist cycle that the country often suffers from, resulting in dictatorships or populism of the left, the center or the right.

Recent history has sought to show the periods through which the country has gone, resulting in a setback situation of half a century or more. The text shows the specifics of this process in Brazil. The university was under attack and espe- 
cially the professor. The first results from the period from FHC to Dilma. With the various programs, especially during Lulism, science became necessary to strengthen the Brazilian condition of platform of production of values. The production of technoscience has become the main target, albeit under intense criticism produced within the university itself. As shown, this was ultimately due to the regime of financial predominance, mediated by the reform of the state apparatus that guided all republican institutions. The university was profoundly affected in all its spheres, for our interest, the professor's work became predominantly productive, and the conditions were extremely precarious and intensified.

An epidemic of suffering, illness and even death resulted from such a change. The pursuit of technoscience by the university, imposed by state policies and pressured by the economic center of capitalism, made these changes a structural fact to the current stage of capitalism. The reduction of the public sphere was drastic, as everything should be ballast to a capital in the form of rotten paper. There was still and there is a pressing threat of over-accumulation. More reforms and new ways of life should emerge. It is emblematic, but not only, first of all it is a crude and cruel reality structurally required for the continuity of capitalism from three flagships: unrestricted outsourcing, labor reform and social security reform.

The first major change requires the worker to work without vacation, thirteenth and without any protection for himself in the field of work. It is up to him to provide for himself and his funds to keep himself alive during periods of unemployment, an accident at work or the bankruptcy of the company in which he works. He is a potential debt taker to survive. The second big change ends all rights in many areas of work. If you need a health insurance plan you should do the same and when you buy the health insurance you take on a lifetime debt to buy a product that you will pay monthly and use more often in the early years and more often with advancing age.

But the most perverse of the big changes is pension reform through capitalization. If approved, the worker will be obliged to buy a private pension plan, therefore, without guarantee of receiving the product at the time of use, because the rules are those of the market. There is no final and legal guarantor. You will pay this product monthly for your lifetime for end-of-life use if you do not die before use. All this time financial institutions will make a lot of money from the fantastic sum of long-term social security contributions, and with a product that does not even go through the "deadly leap of commodity," in Marx's words, since the commodity will only be charged to the institutions. 30 years after (or more) being purchased and paid in thousands of installments.

Such facts caught the attention of [14] [15] [16] [17] [18]. His studies converge on a new feature of capitalism, but one which must be done outside its logic and therefore outside the liberal state and democracy. Harvey deals with Rosa Luxemburg's and Hannah Arendt's theses, which look at the dynamics of capitalism throughout its history. 
The first, in its industrious beginning which through looting, robbery and threats produced the "productive accumulation" and the second, in the structural overthrow of capitalism, the depression of 1929, when the dispossession of the worker came in all forms, unemployment, and its consequences of accumulation of property until the welfare state.

Where the one who profited most from the public fund was capital, an event that began the regime of financial predominance ${ }^{7}$.

The evil of authoritarianism and ultra-conservatism gives reason in this change for which we live. It is necessary to spoil social work by means of a complex system of creating a social debt to be paid by the worker who, in the case of social security, currently works to pay for the commodity to be used a few decades later. Again, social work finances capitalism. It is a growth regime driven by workers' debt. These are not punctual solutions, but structural changes in world capitalism, with consequences for the relationship between countries of the center and the periphery of the world, on the one hand and, on the other, internal by spoiling the Brazilian worker. Poverty is just one more step in a country with over 13 million unemployed.

What can be expected about the future of the university institution and the work within it? It is not difficult to realize that the institution's incessant pursuit will be technoscience, whose products and processes are guided by the workers' debt-driven economy. It pains me to speculate about the work of the research professor, organizing himself from the world economic demand, without research autonomy, that he does not choose his research object because of his existential discomfort, but for what is imposed on him. That he is stranger, suffers sickness and dies many times and many times by suicide. Now he knows that the result of his work contributes directly to the dispossession of workers, yes workers as he is, since his work is productive. The consequences of this current regime called Social-Debt-Led-Growth-Regime are not being analyzed, with the deserved depth. But the scenery is bleak as the boatman Charon moves the boat across the River Styx, taking souls to the other shore. Looks like we're all dead.

\section{Conflicts of Interest}

The author declares no conflicts of interest regarding the publication of this paper.

\section{References}

[1] Bulfinch, T. (2002) O livro de ouro da mitologia: História dos deuses. Tradução de David Jardim Júnior, Rio de janeiro.

[2] Silva Jr., J.R. (2017) The New Brazilian University: A busca por resultados comercializáveis: Para quem?

\footnotetext{
${ }^{7}$ When I write this text. I do it very uneasily in my soul. A friend and a mentor of more than thirty years died-Francisco de Oliveira-stuck here somewhere in the world I cannot pay my last respects. I highlight that the one who first took a look at the kidnapping of the public fund by the capital was my friend Chicão, Professor Emeritus of the University of São Paulo.
} 
[3] Coutinho, C.N. (1984) A democracia como valor universal e outros ensaios. 2 ed. Rio de Janeiro.

[4] Konder, L. (1995) Breve história das ideias socialistas no Brasil. Editora Moderna, Rio de Janeiro.

[5] Cano, W. (1994) Concentración, desconcentración y descentralización en Brasil. In: Curbello. Territorios en Transformación (Análisis y Propuestas), Fondo Europeo de Desarrollo Regional e Consejo Superior de Investigaciones Científicas, Madrid.

[6] Oliveira, F. (1997) Collor: A falsificação da ira. Imago Editora, Rio de Janeiro.

[7] Paulani, L. (1997) Teoria da inflação inercial: um episódio singular na história da ciência econômica no Brasil. In: Garcia Loureiro, M.R., Maria Bianchi, A. and Netto, A.D., Eds., 50 anos de ciência econômica no Brasil: pensamento, instituições, depoimentos, Editora Vozes, Rio de Janeiro.

[8] Marx, K. (1987) Grundrisse: Manuscritos de 1857-1858. Boitempo, São Paulo, 216-238.

[9] Arthur, W.B. (2009) The Nature of Technology: What It Is and How It Evolves. Simon and Schuster, New York.

[10] Bresser-Pereira, L.C. (1996) Crise econômica e reforma do Estado no Brasil. Editora 34, São Paulo.

[11] Paulani, L. (2019) Bolsonaro, o ultraliberalismo e a crise do capital. São Paulo. Margem Esquerda, Revista da Boitempo, 48-56.

[12] Sguissardi, V. and Silva Jr., J.R. (2009) Trabalho intensificado nas federais: pós-graduação e produtivismo acadêmico. Xamã Editora, São Paulo.

[13] Harvey, D. (1992) A condição pós-moderna. Editora Loyola, São Paulo.

[14] Chesnais, F. (1996) A mundialização do capital. Xamã, São Paulo.

[15] Spektor, M. (2013) 18 Dias: Quando Lula e FHC se uniram para conquistar o apoio de Bush. Objetiva, Rio de Janeiro.

[16] Paulani, L. (2008) Brasil Delivery: Servidão financeira e estado de emergência econômico. Boitempo. São Paulo.

[17] Dowbor, L. (2018) A era do capital improdutivo. Autonomia Literária e Outras Palavras, São Paulo.

[18] Harvey, D. (2008) O Neoliberalismo: História e implicações. Editora Loyola, São Paulo. 